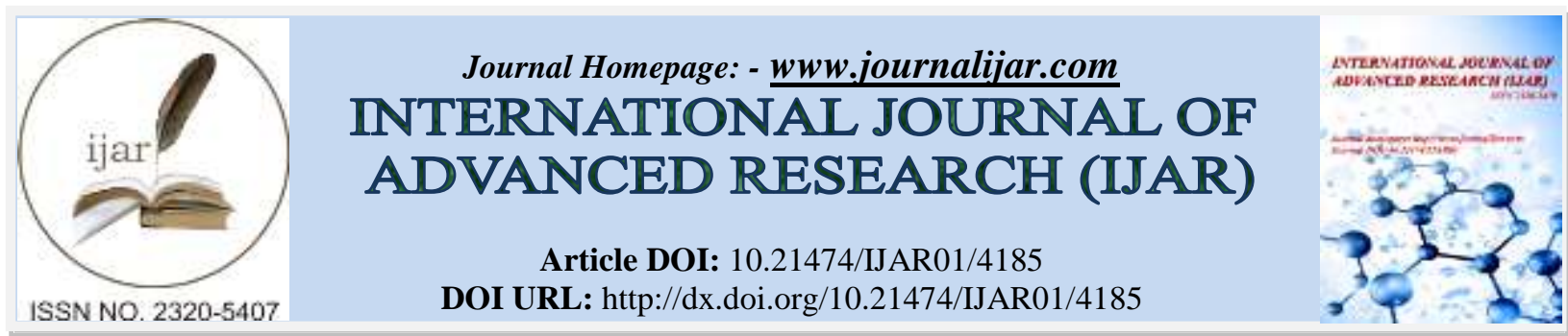

RESEARCH ARTICLE

\title{
ETHNOBOTANICAL STUDIES ON THE RELIGIOUS PLANTS OF SOUNLA VILLAGE OF DISTRICT TEHRI GARHWAL.
}

Parul Singhal, Shivanee and Preeti Dobhal.

Department Of Botany, Alpine Institute Of Management And Technology, Dehradun, Uttarakhand, India.

\section{Manuscript Info}

Manuscript History

Received: 16 March 2017

Published: May 2017

Key words:-

Conservation, Extinction, Rural people, Worship
Final Accepted: 12 April 2017

\begin{abstract}
Hindu religion and culture firmly believed that all constituents of our ambient nature are part and creation of God itself. The God has bestowed some specific powers to certain plants, animals and even rivers, mountains and places which play an important role in human life. Ethnobotany includes all aspects of natural and direct relationship of plants with people. Ethnobotanical knowledge encompasses both wild and domesticated species, and is rooted in observation, relationship, needs and traditional ways of knowing. It can be defined as sacred beliefs, a system of good or evil, faith and worship of supernatural beings and explaining everything in this universe as an act of supernatural beings. There is a need to document the valuable knowledge as it is diminishing very rapidly. During the survey 30 plants belonging to 22 families used for religious purposes have been documented because the local communities and cultures are day by day extincting and with them goes their traditional folklore. An initiative has taken to document the ethnic knowledge regarding the usage of religious plants in Sounla Village of district Tehri Garhwal. The scientific documentation of the plant species which are used in socioculture and religious activities will definitely give encouragement to the local people.
\end{abstract}

Copy Right, IJAR, 2017,. All rights reserved.

\section{Introduction:-}

Uttarakhand, the Mountainous State of Himalayan Region is famous for its religious culture, traditions and pronounced as land of Gods or Devbhoomi. People of this state are highly religious and variety of rituals related to God and Goddess worships are performed in various ways, round the year by the local people in which plants have their defined roles and importance (Sharma and Joshi, 2010). Hindu scriptures tell us that a wide range of plants have divine qualities, hence used in a number of religious activities and rituals right from the marriage till death. These plant species are regularly used by the local people in various religious activities and traditional healing system. The traditional worship practices show the symbiotic relation of human beings and nature. Rural communities all over the world lived in harmony with nature and conserved its valuable biodiversity. The man is using plants in various ways since existence of his life on the earth. They use it in many ways including worshipping Gods and Goddess for the protection and betterment of human life. The preservation of indigenous knowledge with plant and forests may be important tools for conservation of the plant species (Brahma et. al. 2014). Nature and scope of the term ethnobotany be widened to include all aspects like natural and direct relationship with plants of any people, at any level of antiquity, primitiveness or acculturation, and even to the most sophisticated gentlemen

Corresponding Author:- Parul Singhal.

Address:- Department Of Botany, Alpine Institute Of Management And Technology, Dehradun, 833 
and women, if the latter associate any particular plant with festivals or offer flowers or fruits to their Gods or deities (Jain \& Mitra, 1991). "These groups of people are not to be pitied for primitive existence; they rather deserve to be honoured and respected for their richness of human existence in harmony with nature" (Chandra 1990). Indian culture has believes for all happenings in their lives, including sickness and sufferings. Hindu scriptures tell us that a wide range of plants have divine qualities, hence used in a number of religious activities and rituals from birth, baptism, marriage to death. Plant worship as part of nature worship is generally believed to have begun in the initial stage of human society (Sharma and Pegu 2011). In India, various Gods and Goddess are worshipped in different religions throughout the country. Various plant parts like leaves, flower, fruit, bark and twigs are offered to Gods. Almost all the tribal communities consider some plants as holy in origin and essential in religious functions.

\section{Materials and Methods:-}

Study area (Fig. 1):-

Country - India

State - Uttarakhand

District - Tehri Garhwal

Post Office - Binakkhal

Elevation - 5500ft

Language known - Garhwali and Hindi

Sounla village is surrounded by forests. It is connected towards east with Kundi, towards west with gramsabha Thati, towards south with Kundiyali, Binakkhal and also in the southern direction with Givanli gramsabha.

\section{Geographical perspective:-}

Village is located 5500ft above sea level. The Balganga flows in the area and through this river a canal has been made for agriculture use, by which crops are grown and around 15 gramsabhas get water through this river. This river is a lifeline of this village. Climate is moderate. Minimum summer temperarure is $10^{\circ} \mathrm{C}$ and maximum is $30^{\circ} \mathrm{C}$ while the minimum winter temperature is $1{ }^{\circ} \mathrm{C}$ and maximum is $10^{\circ} \mathrm{C}$. Annual rainfall is upto $180 \mathrm{~cm}$. Terrace farming is predominant. Mainly cultivated grasses are Banj, Buransh, Ayern, Khagsi; furniture yielding trees are Chir, Devdar, Thuner; fruit yielding trees are Apple, Pear, Orange, Peach, Chulli, Pulam, Malta, Khumani, religious plants are Peepal, Kela, Tulsi Aam, Bael.

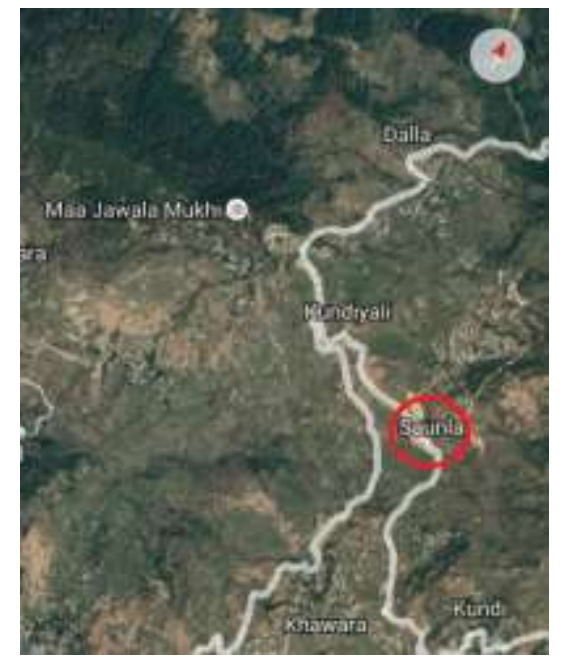

\section{Methodology:-}

Fig. 1:- Map of Sounla Village of District Tehri Garhwal

For information on Ethnobotany of religious plants of Sounla village of district Tehri Garhwal, various field surveys were undertaken in its various rural pockets in different seasons during the year 2015-2016. The desired information on Ethnobotanical aspects was collected through interviews from knowledgeable people (family heads, housewives, elder and experienced persons). Also plant specimens were collected from their natural habitat, dried, preserved and mounted. The specimens were identified by carefully matching with the specimen at the herbarium of Forest Research Institute (FRI). 
Table I:- Religious Plants of Sounla Village of Tehri Garhwal, Uttarakhand.

\begin{tabular}{|c|c|c|c|c|}
\hline $\begin{array}{l}\text { Botanica } \\
\text { l Name }\end{array}$ & $\begin{array}{l}\text { Local } \\
\text { Name }\end{array}$ & Family & Part/s Used & Uses \\
\hline $\begin{array}{l}\text { Aegle } \\
\text { marmelos }\end{array}$ & Bael & Rutaceae & Leaves, Fruits & $\begin{array}{l}\text { Leaves and fruits are used as sacred offerings to Lord Shiva } \\
\text { and considered very dear to Lord Shiva. It is very auspicious } \\
\text { and worshipping Lord Shiva without bael fruits and leaves is } \\
\text { considered to be incomplete. }\end{array}$ \\
\hline $\begin{array}{l}\text { Azadirac } \\
\text { hta } \\
\text { indica }\end{array}$ & Neem & Meliaceae & $\begin{array}{l}\text { Whole plant } \\
\text { specially } \\
\text { leaves }\end{array}$ & $\begin{array}{l}\text { The tree is considered as the symbol of Goddess Durga or Maa } \\
\text { Kali. Neem is considered as abode of Sitala (the great pox - } \\
\text { mother who can cause or cure disease). Pox is treated by } \\
\text { rubbing the body with neem leaves while praying her. The } \\
\text { smoke of burning neem leaves protects both the living and the } \\
\text { dead from evil spirits. }\end{array}$ \\
\hline $\begin{array}{l}\text { Brassica } \\
\text { campestri } \\
\text { s }\end{array}$ & $\begin{array}{l}\text { Sarso } \\
\text { on }\end{array}$ & $\begin{array}{l}\text { Brassicace } \\
\text { ae }\end{array}$ & Seeds (oil) & $\begin{array}{l}\text { Oil from seeds is used for lightening Deepak or jyot. Oil dhara } \\
\text { is performed on the Shivlinga for stopping the evil effects of } \\
\text { enemies. It is also believed that it also gives success in } \\
\text { business. }\end{array}$ \\
\hline $\begin{array}{l}\text { Calotropi } \\
s \\
\text { gigantea }\end{array}$ & $\begin{array}{l}\text { Safed } \\
\text { aak }\end{array}$ & $\begin{array}{l}\text { Asclepiad } \\
\text { aceae }\end{array}$ & Whole plant & $\begin{array}{l}\text { Ak is believed to be the daughter of God Surya. Thus, a man } \\
\text { getting married with this plant will become safe from evil } \\
\text { effects and his married life will be blessed }\end{array}$ \\
\hline $\begin{array}{l}\text { Cannabis } \\
\text { sativa }\end{array}$ & $\begin{array}{l}\text { Bhaa } \\
\text { ng }\end{array}$ & $\begin{array}{l}\text { Cannabac } \\
\text { eae }\end{array}$ & $\begin{array}{l}\text { Dried young } \\
\text { leaves and } \\
\text { flowering tops. }\end{array}$ & $\begin{array}{l}\text { Hindus use plant in religious ceremonies. Bhang made from } \\
\text { drying the young leaves and flowering tops offers to Lord } \\
\text { Shiva to please him. During the festival of Mahashivratri, the } \\
\text { plant is consumed in a religious drink called bhang. }\end{array}$ \\
\hline $\begin{array}{l}\text { Capsicu } \\
\text { m annum }\end{array}$ & $\begin{array}{l}\text { Hari } \\
\text { mirch }\end{array}$ & $\begin{array}{l}\text { Solanacea } \\
\mathrm{e}\end{array}$ & Fruit & $\begin{array}{l}\text { Green chillies and lemon are hanged outside shops by the } \\
\text { people on every Saturday for protection against evil eyes. Also } \\
\text { hanged on new vehicles for the same. }\end{array}$ \\
\hline $\begin{array}{l}\text { Cedrus } \\
\text { deodara }\end{array}$ & $\begin{array}{l}\text { Deod } \\
\text { ar }\end{array}$ & Pinaceae & Whole plant & $\begin{array}{l}\text { Tree is a symbol of prosperity and considered as the tree of } \\
\text { Gods. In the Hindu religion deodars are worshipped as divine } \\
\text { trees and are referred to in several of their legends. According } \\
\text { to Hindu mythology, Lord Shiva was meditating under a } \\
\text { deodar tree when Kamdev shot his arrow of love, disturbing } \\
\text { him and thereby incurring his wrath. In the western Himalayas, } \\
\text { the deodar is closely linked with worship of Shiva and cluster } \\
\text { of devdars are usually found around Shiva temple. }\end{array}$ \\
\hline $\begin{array}{l}\text { Curcuma } \\
\text { longa }\end{array}$ & Haldi & $\begin{array}{l}\text { Zingibera } \\
\text { ceae }\end{array}$ & Rhizome & $\begin{array}{l}\text { Rhizome considered sacred and turmeric paste is applied to the } \\
\text { body of the bride before marriage. On religious occasions } \\
\text { turmeric is applied to the forehead of devotees and also to the } \\
\text { statues of Gods. }\end{array}$ \\
\hline $\begin{array}{l}\text { Cynodon } \\
\text { dactylon }\end{array}$ & $\begin{array}{l}\text { Durw } \\
\text { a, } \\
\text { Hariy } \\
\text { alli }\end{array}$ & Poaceae & Whole plant & $\begin{array}{l}\text { People use doob in every religious ceremony at the time of } \\
\text { wedding of young girl. Hindus believe that by offering doob to } \\
\text { Lord Ganesha all pains and evils will be destroyed. }\end{array}$ \\
\hline $\begin{array}{l}\text { Datura } \\
\text { metel }\end{array}$ & $\begin{array}{l}\text { Datur } \\
\text { a }\end{array}$ & $\begin{array}{l}\text { Solanacea } \\
\mathrm{e}\end{array}$ & $\begin{array}{l}\begin{array}{l}\text { Flowers and } \\
\text { fruits }\end{array} \\
\end{array}$ & Flowers and fruits are offered to please God Shiva. \\
\hline $\begin{array}{l}\text { Elaeocar } \\
\text { pus } \\
\text { ganitrus }\end{array}$ & $\begin{array}{l}\text { Rudra } \\
\text { ksh }\end{array}$ & $\begin{array}{l}\text { Elaeocarp } \\
\text { aceae }\end{array}$ & Fruit & $\begin{array}{l}\text { Rudraksh is considered as the tear of 'Lord Shiva' and a shield } \\
\text { against negative energies by the local people. Garland made } \\
\text { from fruits of the plant is also offered to please Lord Shiva. It is } \\
\text { believed that a person wearing a garland of rudraksh, that } \\
\text { person will go to the heaven after his death. }\end{array}$ \\
\hline $\begin{array}{l}\text { Emblica } \\
\text { officinali } \\
S\end{array}$ & Aonla & $\begin{array}{l}\text { Euphorbia } \\
\text { ceae }\end{array}$ & Whole plant & $\begin{array}{l}\text { It is believed that Goddess Lakshmi resides in the tree. It is } \\
\text { worshipped because it cures lot of illness. This tree is } \\
\text { worshipped on 'Amli Ekadashi'. }\end{array}$ \\
\hline $\begin{array}{l}\text { Ficus } \\
\text { benghale }\end{array}$ & $\begin{array}{l}\text { Barga } \\
\mathrm{d}\end{array}$ & Moraceae & Whole plant & $\begin{array}{l}\text { Women worship the tree on "Jesth Shudhao", water it and also } \\
\text { tie a thread around it. }\end{array}$ \\
\hline
\end{tabular}




\begin{tabular}{|c|c|c|c|c|}
\hline$n s i s$ & & & & \\
\hline $\begin{array}{l}\text { Ficus } \\
\text { religiosa }\end{array}$ & Pipal & Moraceae & $\begin{array}{l}\text { Leaves and } \\
\text { dried twigs }\end{array}$ & $\begin{array}{l}\text { Considered one of the leading trees in Hinduism and } \\
\text { Buddhism. Also known as Bodhi tree because Gautam Buddha } \\
\text { attained enlightenment under it. It is sacred to Vishnu. Leaves } \\
\text { are considered auspicious for Panchapallava (a string of five } \\
\text { leaves of Pipal or mango). Leaves are tied around the waist of } \\
\text { person for performing janeu or marriage ceremony. It is } \\
\text { believed that panchpallav gives protection against devils and } \\
\text { evil spirits. The wood or dried twigs are used for performing } \\
\text { havan. }\end{array}$ \\
\hline $\begin{array}{l}\text { Gossypiu } \\
m \\
\text { arboreum }\end{array}$ & Rui & $\begin{array}{l}\text { Malvacea } \\
\mathrm{e}\end{array}$ & Fruit and seeds & $\begin{array}{l}\text { The fibres are used to make batti (thick thread or wick) which } \\
\text { is used to lighten Diya during the worshipping of God, } \\
\text { Goddess and Pitrapuja. It is believed that by making one lakh } \\
\text { and twenty five thousand wicks and light them on the name of } \\
\text { the God and Goddess, his or her progenies and ancestors will } \\
\text { get rid of all sins up to seven generations. }\end{array}$ \\
\hline $\begin{array}{l}\text { Hibiscus } \\
\text { rosa- } \\
\text { sinensis }\end{array}$ & $\begin{array}{l}\text { Gudh } \\
\text { al }\end{array}$ & $\begin{array}{l}\text { Malvacea } \\
\text { e }\end{array}$ & Flowers & Flowers offered to Gods and Goddesses to please them \\
\hline $\begin{array}{l}\text { Hordeum } \\
\text { vulgare }\end{array}$ & Jau & Poaceae & Seeds & $\begin{array}{l}\text { Seeds are considered pure. People use seeds for 'Havan', } \\
\text { worshipping and other social ceremonies. }\end{array}$ \\
\hline $\begin{array}{l}\text { Juglans } \\
\text { regia }\end{array}$ & $\begin{array}{l}\text { Akhr } \\
\text { ot }\end{array}$ & $\begin{array}{l}\text { Juglandac } \\
\text { eae }\end{array}$ & Fruit & $\begin{array}{l}\text { A mixture of five dry fruits (viz. akhrot, kaju, kishmish, badam, } \\
\text { chuwara) locally called Panchmewa and is generally used in } \\
\text { religious ceremonies. }\end{array}$ \\
\hline $\begin{array}{l}\text { Mangifer } \\
\text { a indica }\end{array}$ & Aam & $\begin{array}{l}\text { Anacardia } \\
\text { ceae }\end{array}$ & $\begin{array}{l}\text { Leaves, wood } \\
\text { and fruits }\end{array}$ & $\begin{array}{l}\text { Leaves used for preventing evil spirits. Wood is used to } \\
\text { perform 'havan' and various pujas because its wood gets easily } \\
\text { burnt with smoke. Mango leaves are usually tied around kalash } \\
\text { during 'pujas' which is dedicated to Lord Vishnu. Some people } \\
\text { tie leaves at the entrance of their houses because they bring } \\
\text { good luck and prosperity. Fruits used on Basant Panchmi for } \\
\text { worshipping Goddess 'Saraswati'. }\end{array}$ \\
\hline $\begin{array}{l}\text { Musa } \\
\text { sapientu } \\
m\end{array}$ & Kela & Musaceae & $\begin{array}{l}\text { Whole plant } \\
\text { specially } \\
\text { leaves }\end{array}$ & $\begin{array}{l}\text { Fruits edible. It is considered pure and holy fruit used in } \\
\text { religious ceremonies like 'katha' and 'vivah'. Tree is also } \\
\text { worshipped on every Thursday by the people. }\end{array}$ \\
\hline $\begin{array}{l}\text { Ocimum } \\
\text { sanctum }\end{array}$ & Tulsi & $\begin{array}{l}\text { Lamiacea } \\
\mathrm{e}\end{array}$ & $\begin{array}{l}\text { Whole plant } \\
\text { specially } \\
\text { leaves and } \\
\text { seeds }\end{array}$ & $\begin{array}{l}\text { Plant is considered sacred for worship of Vishnu and his avtars } \\
\text { Krishna and Hanuman. It is worshipped as the avtar of } \\
\text { Lakshmi. Offering leaves are mandatory in ritualistic worship } \\
\text { of Vishnu and his avtars. Tulsi mala is considered to be } \\
\text { auspicious for the wearer and believed to make contact with } \\
\text { Vishnu or Krishna and confer the protection of the deity. }\end{array}$ \\
\hline $\begin{array}{l}\text { Oryza } \\
\text { sativa }\end{array}$ & Dhan & Poaceae & Seeds & $\begin{array}{l}\text { Rice is used in religious ceremonies of the Hindus, associated } \\
\text { with both birth and marriage. Seeds donated to Brahmins. It is } \\
\text { believed that all crops are boon of Gods. The rice is used for } \\
\text { making pudding and also offered to Gods. }\end{array}$ \\
\hline $\begin{array}{l}\text { Pinus } \\
\text { roxburgh } \\
\text { ii }\end{array}$ & Chir & Pinaceae & Wood & Wood is used in 'Havan' or 'Yagya'. \\
\hline $\begin{array}{l}\text { Prosopis } \\
\text { cineraria }\end{array}$ & Sami & $\begin{array}{l}\text { Mimosace } \\
\text { ae }\end{array}$ & Wood & $\begin{array}{l}\text { The worship of Shami is called as Shami Pujan. Shami wood is } \\
\text { also used in Pujan. }\end{array}$ \\
\hline $\begin{array}{l}\text { Saccharu } \\
m \\
\text { officinaru } \\
m\end{array}$ & $\begin{array}{l}\text { Gann } \\
a\end{array}$ & Poaceae & Stem & Erect stems are used to make holy mandap of marriage. \\
\hline $\begin{array}{l}\text { Santalum } \\
\text { album }\end{array}$ & $\begin{array}{l}\text { Chan } \\
\text { dan }\end{array}$ & $\begin{array}{l}\text { Santalacea } \\
\text { e }\end{array}$ & Wood & $\begin{array}{l}\text { The heartwood of sandal is used in religious pujas to make } \\
\text { chandan pastes. These pastes are applied on the forehead of }\end{array}$ \\
\hline
\end{tabular}




\begin{tabular}{|l|l|l|l|l|}
\hline $\begin{array}{l}\text { Saraca } \\
\text { indica }\end{array}$ & $\begin{array}{l}\text { Ashok } \\
a\end{array}$ & $\begin{array}{l}\text { Caesalpini } \\
\text { aceae }\end{array}$ & Whole plant & $\begin{array}{l}\text { Gods and Goddesses. Worship stick also used in such pujas. } \\
\text { In Hindu mythology Ashoka tree is considered as a sacred tree. } \\
\text { The tree usually worshipped in Chaitra, the first month of } \\
\text { Hindu Calendar. Only women worship the tree. The Hindus } \\
\text { regarded it as sacred and being dedicated to Kamadeva, God of } \\
\text { Love. It is considered sacred because these trees gave shelter to } \\
\text { Goddess 'Sita' in Ashoka Vatika' during exile, where she was } \\
\text { kept by 'Ravana' }\end{array}$ \\
\hline $\begin{array}{l}\text { Shorea } \\
\text { robusta }\end{array}$ & Sal & $\begin{array}{l}\text { Dipterocar } \\
\text { paceae }\end{array}$ & $\begin{array}{l}\text { Whole plant } \\
\text { specially } \\
\text { leaves } \\
\text { wood }\end{array}$ & $\begin{array}{l}\text { Tree is considered as a favourite tree of Lord 'Vishnu'. Leaves } \\
\text { are used to prepare patravali (plate) and Duno (small bowl), } \\
\text { which are used in all ritual functions and are regarded as } \\
\text { uncontaminated. Its wood is also used to make 'Suro' (palm } \\
\text { like structure) for Havan. }\end{array}$ \\
\hline $\begin{array}{l}\text { Triticum } \\
\text { aestivum }\end{array}$ & $\begin{array}{l}\mathrm{n} \\
\mathrm{n}\end{array}$ & Pohu & Seeds & $\begin{array}{l}\text { Wheat flour is used to prepare chapattis and also to prepare } \\
\text { sweet dish (halwa) for offering to God and worshipping. Seeds } \\
\text { are used for Grahashanti especially in Rahu Grahshanti. }\end{array}$ \\
\hline $\begin{array}{l}\text { Zanthoxy } \\
\text { lum } \\
\text { armatum }\end{array}$ & Timru & Rutaceae & Branches & $\begin{array}{l}\text { Branches are worshipped in Janeu sanskar and in a folk dance } \\
\text { (Jagar). It is considered as a symbol of folk God 'Narsingha'. }\end{array}$ \\
\hline
\end{tabular}

\section{Discussion:-}

People of the village Sounla are deeply religious and it is clear from the documentation of 30 species under 29 genera and 22 families. During present investigation these 30 species were recorded to be used for the religious purposes (Table 1). Overall diversity grouped equally into 15 wild species and 15 cultivated. Herbs were dominating with 57\% species followed by trees (38\%) and shrubs (5\%) (Figure 2). A large majority of collected taxa flowers and fruits during summer (53\%) followed by spring (37\%), winter (7\%) and autumn (3\%) (Fig 3 and 4).

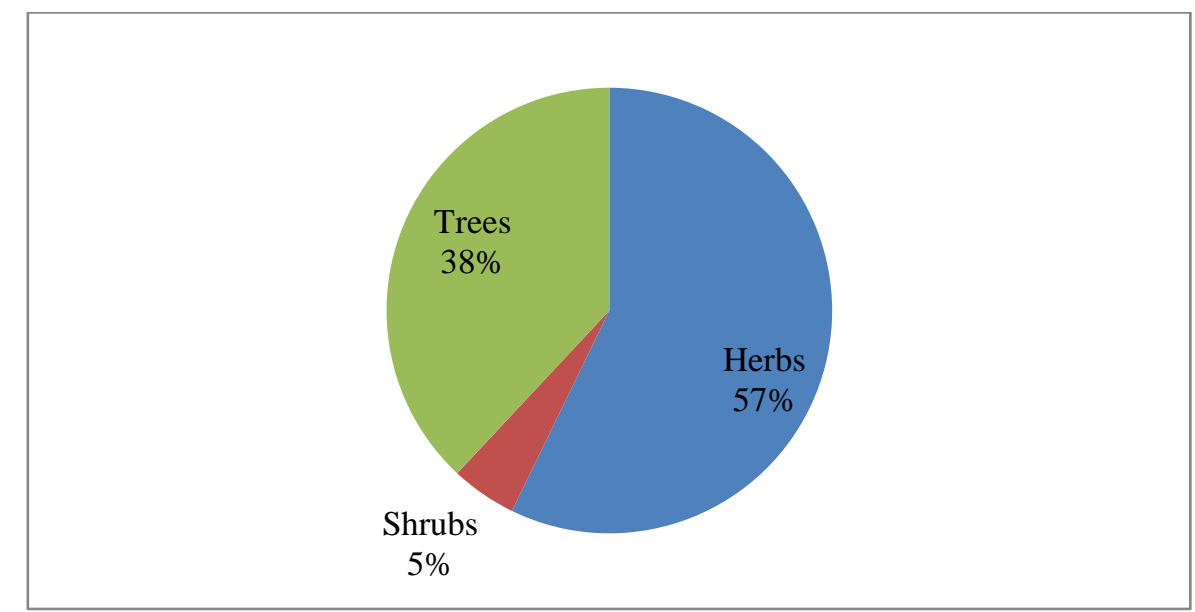

Fig.2:- Relative Percentage of Ethnobotanically collected Herbs, Shrubs, and Trees of the Sounla Village of District Tehri Garhwal 


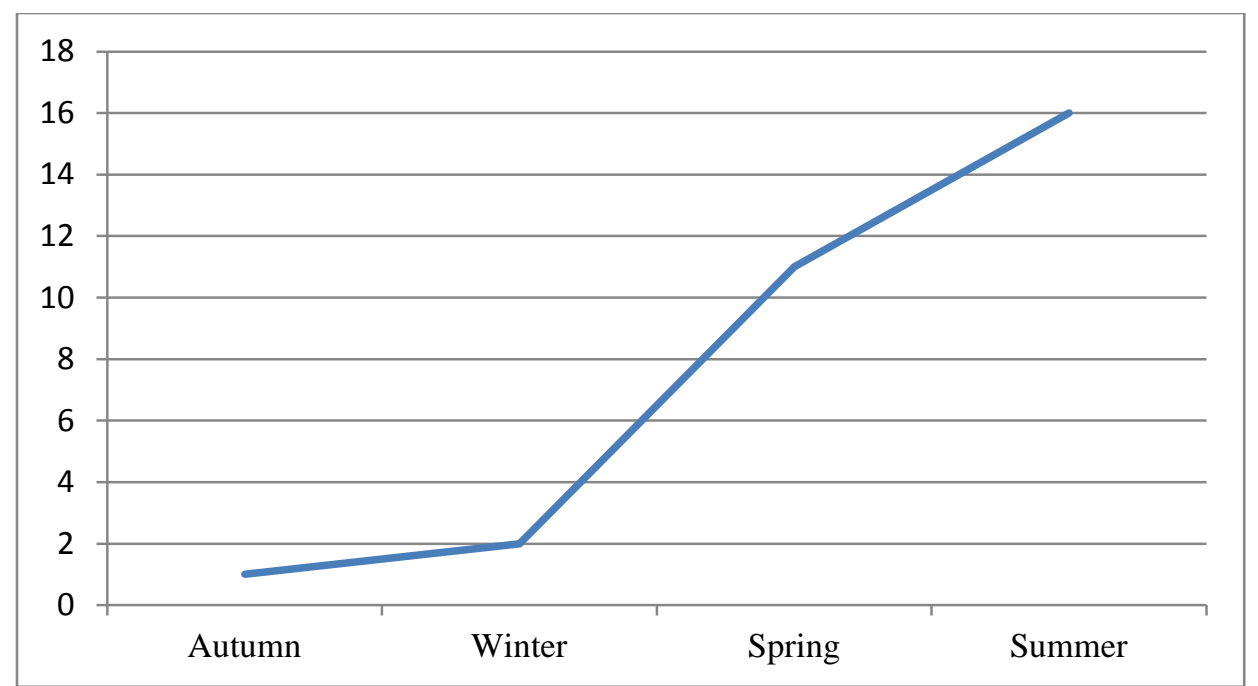

Fig.3:- Graph showing the flowering and fruiting seasons of plants used by rural populace of the Sounla Village of District Tehri Garhwal

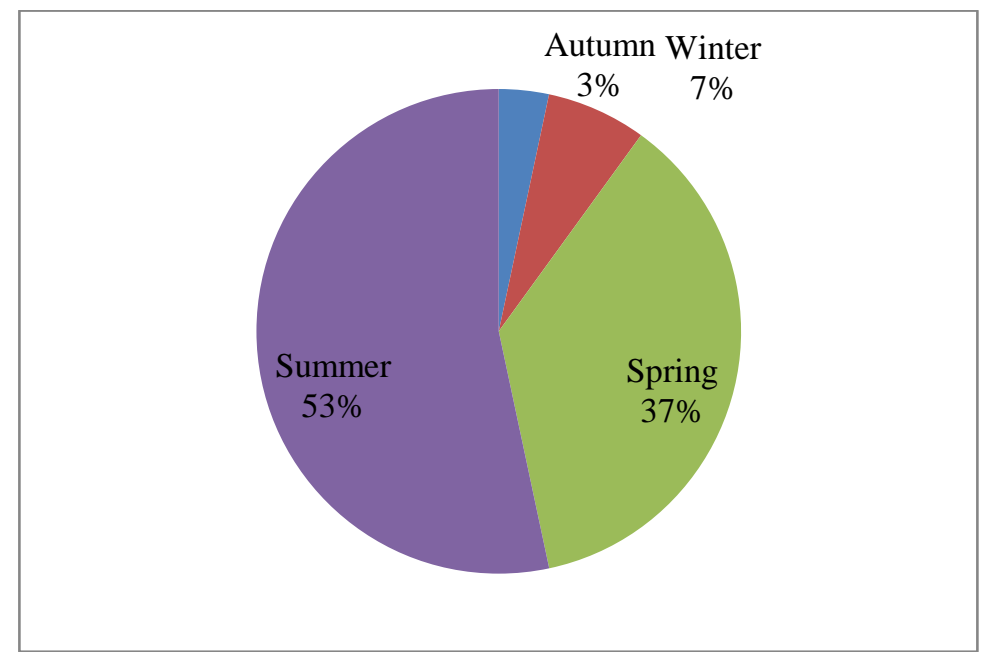

Fig.4:- Pie diagram showing relative percentage of flowering and fruiting seasons of collected ethnobotanical plants by rural populace of the Sounla Village of District Tehri Garhwal.

\section{Conclusion:-}

The traditional worship practices show the symbiotic relation of human beings and nature. Indigenous communities all over the world lived in harmony with the nature and conserved its valuable biodiversity. This particular village is not only enriched in religious plants but other ethno botanical plants also. The search for economic plants used by tribes and aboriginals must continue. The tribal communities and cultures are day by day extincting and with them goes their traditional folklore. Due to more urbanization and modernization, our ethics and religious concepts are fading away. This information will be very helpful to the present and future generation and thus, they will be able to preserve our ethics. The preservation of ethnobotanical diversity in the prevailing ecosystems should form an important item in any overall plan for development in rural areas. It is to uncover these hidden and secret uses of the flora that ethnobotany has become an important part of our investigation (Jain and Rao,1983). 


\section{References:-}

1. Brahma, S., Narzary, H. \& Brahma, J. (2014). Socio-cultural and Religious plants used by BODO tribes of BTC Assam, India. International Journal of Scientific Research Publications, vol-4, Issue-1.

2. Chandra, S. (1990). Foundations of Ethnobotany (Pre- 1900 Ethnobotany). Deep Publ. New Delhi.

3. Jain, S. K. \& Mitra, R. (199)1. Ethnobotany in India: retrospect and prospect, 1018. In: Jain, S. K. (ed.) Contribution to Indian Ethnobotany. Sci. Publ., Jodhpur.

4. Jain, S. K. \& Rao, R. R. (1983). Ethnobotany in India- An Overview. Botanical Survey of India, Howrah. pp. 22

5. Sharma, V. \& Joshi, B. D. (2010). Role of Sacred Plants in Religion and Health- care system of local people of Almora District of Uttarakhand State (India). Academia area, 2(6):19-22.

6. Sharma, U. K. \& Pegu S. (2011). Ethnobotany of religious and supernatural beliefs of the Mising tribes of Assam with special reference to the Dobur Uie. Journal Ethnobiology and Ethnomedicine. 7:16. 